10. Пельо І.М. Обгрунтування методологічних підходів до здійснення санітарного контролю продуктів овочівництва та грунту при застосуванні сумішей пестицидів. Медична наука України. 2015. Т. 11. № 1-2. C. 84-90.

11. Vavrinevych O.P., Antonenko A.M., Omelchuk S.T. [et al.]. Prediction of pesticide risks to human health by drinking water extracted from underground sources. Georgian medical news. 2015. № 5 (242). P. 77-84.

12. Spadotto C.A. Screening method for assessing pesticide leaching potential. Pesticidas: R. Ecotoxicol. Curitiba. 2002. Vol. 12. P. 69-78.

13. PPDB: Pesticide Properties Data Base. URL: http://sitem.herts.ac.uk/aeru/footprint/en/. (Date of access 18.09.2020).

DOI https://doi.org/10.30525/978-9934-588-81-5-2.44

\title{
ПСИХОГІГІЕНІЧНІ МЕТОДИ КОРЕКЦІЇ ДОНОЗОЛОГІЧНИХ ПСИХІЧНИХ СТАНІВ У ДІТЕЙ 3 ВАДАМИ СЕНСОРНОЇ СИСТЕМИ
}

Герасименко О. I. кандидат біологічних наук, доиент кафедри гігієни та екології № 1 Харківський національний медичний університет

Кателевська Н. М. кандидат медичних наук, дочент кафедри гігієни та екологї № 1 Харківський національний медичний університет

Богачова О. C. кандидат медичних наук, старший викладач кафедри гігієни та екології № 1 Харківський національний медичний університет

Колоша О. В. здобувач вищої освіти

Харківський національний медичний університет м. Харків, Украӥна

Забезпечення соціального благополуччя дітей з особливими потребами, зокрема, обумовленими патологією сенсорної системи, є ознакою держави, в якій гідний розвиток і захист прав іїі громадян забезпечується з дотриманням принципів демократії, рівності, миру, соціальної справедливості з урахуванням моральних засад та традиційних 
цінностей. Відображенням успішності суспільства, соціальної захищеності та рівня і якості здоров'я підростаючого покоління є рівень соціальної адаптованості дітей із вадами розвитку, зокрема, сенсорною системи. Невідповідність рівня соціальної адаптованості дитини 3 вадами сенсорної ситеми, її непристосованість або несприяняття себе як невід'ємної частини суспільства є фактором ризвитку донозологічних психічних станів у дітей з вадами сенсорної системи.

Метою нашої роботи був аналіз психогігієнічних методів корекції донозологічних психічних станів у дітей з вадами сенсорної системи.

Основні психогігієнічні заходи 3 корекції донозологічних психічних станів, попередження та (або) подалання попередження та подолання ситуацій, періодів та станів ризику в спеціалізованих школах для дітей з патологією сенсорної системи повинні включати наступні форми роботи.

Санітарна просвіта, як сукупність освітніх, виховальних, агітаційних і пропагандистських заходів налаштованих на збереження і зміцнення психічного здоров'я підліт ків. Різні форми санітарної просвіти повинні бути орієнтовані не тільки на окрему особистість, але і на колективи підлітків (малі групи, навчальні класи або групи тощо) i спрямовані не тільки на засвоєння учнями знань про негативні наслідки поведінки ризику, а і на актуалізацію знань підлітків щодо різноманітних заходів для формування здорового способу життя.

Психокорекційні методи, метою яких є зміцнення психологічної стійкості підлітків і гармонізація їх особистісного розвитку. В контексті первинної психопрофілактики, доцільно застосовувати лише ті методи і в тих модифікаціях, які сприяють динамічному розвитку особистості та її більш повній адаптації до умов навчання і життя в цілому.

Для ефективного проведення психопрофілактичних заходів доцільно обладнати у кожному навчальному закладі, зокрема у спеціальному навчальному закладі для дітей з вадами сенсорної системи, спеціальні кабінети психогігієни

Одним з ефективних відео-профілактичних методів корекції деяких донозологічних психічних станів і негативних проявів акцентуацій характеру особистості може бути демонстрація підліткам спеціально підібраних художніх і науково-популярних фільмів та відеосюжетів психопрофілактичної з послідуючим їх обговоренням за участю психолога. Спрямованості доцільно використовувати заходи атрпсихопрофілактики, які в сучасному суспільстві визначаються, як найбільш продуктивні та багатофункціональні серед заходів первинної профілактики донозологічних психічних станів у підлітків з особливими потребами, зокрема з вадами сенсорної системи. 